УДК 633.12:631,53.04, DOI 10.31210/visnyk2018.02.28

(C) 2018

Ульянченко М. С., здобувач

(науковий керівник - кандидат сільськогосподарських наук, професор О. М. Куиенко)

Полтавська державна аграрна академія

\title{
ВПЛИВ СТРОКІВ СІВБИ НА ПРОДУКТИВНІСТЬ ГРЕЧКИ
}

\section{Рецензент - кандидат сільськогосподарських наук М. І. Кулик}

На фоні нестабільних погодних умов весняного періоду, що відмічаються останнім часом, встановлення оптимальних строків сівби районованих сортів гречки набуває актуального значення.

У статті експериментальним шляхом вивчали шість сортів гречки (Fagopyrum esculentum Moench) вітчизняної селекиї: Ярославна, Слобожанка, Руслана, Украйнка, Крупинка, СИН-3/02 залежно від строків сівби в умовах нестійкого зволоження центрального Лісостепу. Для проведення досліджень використовували загальноприйняті та спеціальні методики: продуктивність сортів гречки та аналіз зернового матеріалу за елементами продуктивності визначали після очищення зерна методом повітряної сепарації та перерахунку на стандартну $14 \%$ вологість.

Для умов 2015 року встановлено, щьо елементи продуктивності гречки (крупність та кількість зерен з рослини) мають суттєвий вплив на формування продуктивності культури. За масою 1000 зерен виокремилися сорт Крупинка за раннього строку сівби, суттєво менші значення отримали за иим показником у сортів Слобожанка та Українка, відповідно, за сівби в перший та другий строк. Усі інші сорти за крупністю зерна мали середнє значення. Строки сівби сорту СИН-3/02 не мали впливу на елементи продуктивності.

В умовах 2016 року за крупністю зерна виокремилися сорти Ярославна, Руслана та Крупинка за раннього та середнього строків сівби. Всі сорти, щзо вивчалися, забезпечили вищу крупність зерна за раннього строку сівби, за виключенням сортів Ярославна та Украӥнка.

За результатами дворічних досліджень визначено, що ранньостиглі сорти гречки Ярославна і Руслана доиільно висівати з середини першої декади травня. Сорти Слобожанка і Крупинка формують найбільиу продуктивність за сівби в периий та другий строк. Чіткого впливу терміну сівби на даний показник у сортів СИН-3/02 та Українка не виявлено.

Ключові слова: сорти, метеорологічні умови, кількість зерен, кількість опадів, температура повітря.

Постановка проблеми. Жоден прийом вирощування гречки не обходиться так дешево i, мабуть, не має настільки значного впливу на ii врожайність, як термін сівби. Вчасно посіяти значить отримати високий урожай без будь- яких додаткових витрат праці та коштів [3].

Прогнозування оптимальних термінів сівби гречки має виняткове значення, оскільки всім хліборобам добре відома велика залежність врожаю від метеорологічних умов. Проблема встановлення оптимальних термінів сівби дуже складна і потребує подальшої наукової розробки.

Аналіз основних досліджень і публікацій, у яких започатковано розв'язання проблеми. У гречки погодні умови визначають врожайність більше, ніж у багатьох інших сільськогосподарських культур. За термінами сівби - це пізня культура, однак у разі запізнення з сівбою цвітіння ¥ї може співпасти 3 настанням високих температур, що різко знижує врожай. Ранній вибір строку сівби призведе до ушкодження або навіть загибелі сходів від весняних приморозків. Тому дослідники прагнуть знайти такий весняний строк, коли б виключалась шкідлива дія температур $[1,6]$.

У різних грунтово-кліматичних зонах найкращі агротехнічні строки сівби гречки в залежності від умов весни щороку складаються по-різному. Аналіз наукових і виробничих даних показує, що сівба гречки при настанні оптимальних строків сівби в конкретному районі зазвичай забезпечує більш високі врожаї [5]. Дослідженнями наукових установ і досвідом передових господарств встановлено оптимальні строки сівби гречки для різних грунтово-кліматичних зон ii обробітку. Однак вони дещо змінюються і уточнюються в залежності від ряду конкретних умов господарства.

Не так давно багато дослідників пропонували сіяти гречку в 2-3 строки, щоб хоча б один із них забезпечив отримання високого врожаю. Зараз із цим погодитися не можна. Сучасний стан науки дає повну можливість встановлення оптимальних термінів сівби вибраних сортів у всіх районах обробітку гречки. Причому найбільш ефективним i оптимальним вважається ранній термін сівби гречки. У цьому випадку зберігаються весняні запаси вологи в грунті, рослини не страждають від високих температур i суховіїв під час цвітіння і формування зерна [8]. 


\section{СТОРІНКА МОЛОДОГО ВЧЕНОГО}

Мета досліджень - встановити оптимальний строк сівби гречки (F. esculentum M.) в умовах нестійкого зволоження центрального Лісостепу, за якого формуватиметься максимальна продуктивність сорту.

Завдання досліджень передбачали вивчення впливу строків сівби на продуктивність сортів гречки залежно від умов вирощування.

Матеріали та методи досліджень. Програму наукових досліджень проводили на полях Устимівської ДСР (дослідної станції рослинництва) Інституту рослинництва імені В. Я. Юр'єва НААН (Національної академії аграрних наук) України протягом 2015-2016 років. Станція розміщена в центральній частині Лівобережжя, безпосередньо на кордоні між Лісостеповою та Степовою зонами, в південно-східній частині Полтавської області (географічні координати: $49^{0} 18^{1}$ північної широти та $39^{0} 14^{1}$ східної довготи) за 30 км від міста Кременчука.

Устимівська ДСР розташована на рівному відкритому цілком безлісому Полтавському плато лівобережних терас річки Дніпра, що має незначний нахил до заходу, на середньосуглинкових потужних чорноземах із вкрапленнями солонцюватих грунтів. Основною грунтоутворюючою породою є карбонатний лес (однорідна порода, пухка, палевого кольору). За механічним складом він належить до середніх суглинків. Характерною особливістю лесу $є$ його карбонатність, водопроникність і пухкість.

У результаті польового обстеження і даних лабораторних аналізів, що проводила Полтавська обласна проектна станція хімізації сільського господарства, встановлено, що вміст гумусу (за Тюріним) в шарі грунту 0-20 см складає 3,84 \%. У більш глибоких шарах грунту кількість його зменшується і на глибині 80-90 см його вміст складає близько $2,1 \%$. В орному шарі грунту (0-20 см) вміщується в середньому: рухомих форм фосфору $\left(\mathrm{P}_{2} \mathrm{O}_{5}\right)-20,6 \mathrm{Mг} / 100$ г, калію $\left(\mathrm{K}_{2} \mathrm{O}\right)-10,2$ мг/100 г. Реакція грунтового розчину - слабо-кисла, $\mathrm{pH}$ соляне - 5,8-6,1.

Вихідним матеріалом для досліджень були районовані сорти гречки: Ярославна, Слобожанка, Руслана, Українка, Крупинка, СИН-3/02 [2].

Польові досліди розміщували в селекційнонасінницьких сівозмінах, де вивчали вплив строків сівби на продуктивність перспективних сортів гречки. Попередник - пшениця озима. Застосовували загальноприйняту технологію вирощування гречки, за виключенням досліджуваних параметрів.

Сівбу проводили в три оптимальні строки 3 рендомізованим розміщенням ділянок у чотирикратній повторності 3 нормою висіву 250 зерен на м². Загалом заклали 72 ділянки. Застосовували звичайний рядковий спосіб сівби 3 міжряддям 15 см. Сіяти починали в 2015 і 2016 роках 6.05 , з інтервалом у 5 днів. Відповідно, наступними строками сівби були $11 \mathrm{i}$ 16 травня. Якість насіння - перша репродукція, чистота $-100 \%$. Лабораторна схожість - 97$99 \%$.

Збирання дослідного матеріалу проводили вручну серпами, в міру достигання зразків. Зібрані рослини перевозили під накриття і через 7 діб здійснювали їх обмолот за допомогою молотарки терки пучкової універсальної («МТПУ-500»).

Продуктивність сортів гречки та аналіз зернового матеріалу (маса 1000 насінин, маса і кількість насіння $з$ рослини, крупність, вирівняність тощо) визначали в лабораторії Устимівської ДСР Інституту ім. В. Я. Юр'єва НААН України після очищення зерна методом повітряної сепарації та перерахунку на стандартну $14 \%$ вологість.

Статистичний аналіз результатів польових дослідів виконували за допомогою дисперсійного та статистичного методів, згідно 3 «Методикою польового досліду» Б. О. Доспєхова (1985) та «Комп'ютерних методів у сільському господарстві та біології» О. М. Царенка, Ю. А. Злобіна, В. Г. Скляра (2000) 3 використанням комп'ютерних програм Excel 2010 i Statistica $6[4,7]$.

Результати досліджень. Вегетаційний період 2015 року характеризувався теплою і вологою весною, що дало змогу провести сівбу в оптимальні строки у вологий грунт і на фоні помірних температур отримати дружні сходи. Травень виявився дощовим, за 8 днів випало 56,5 мм опадів за багаторічного показника 50,0 мм.

У червні випало 123,5 мм опадів за середнього багаторічного показника 57,0 мм. Середньомісячна температура повітря становила $21,0{ }^{\circ} \mathrm{C}$ за багаторічного значення $19,5^{\circ} \mathrm{C}$. Липень був спекотним, за 7 дощових дні випало 46,7 мм опадів за середнього багаторічного значення 72,0 мм.

Середня температура повітря в липні становила $22,8{ }^{\circ} \mathrm{C}$ за багаторічного показника $21,0{ }^{\circ} \mathrm{C}$. У серпні спостерігалась суха і тепла погода, впродовж місяця випало 9,0 мм опадів, що на 49,0 мм нижче за норму (58,0 мм). Середня температура повітря становила $23,0^{\circ} \mathrm{C}$ за середнього багаторічного показника $19,8^{\circ} \mathrm{C}$. Серпень був сприятливим для збирання гречки (рис. 1). 


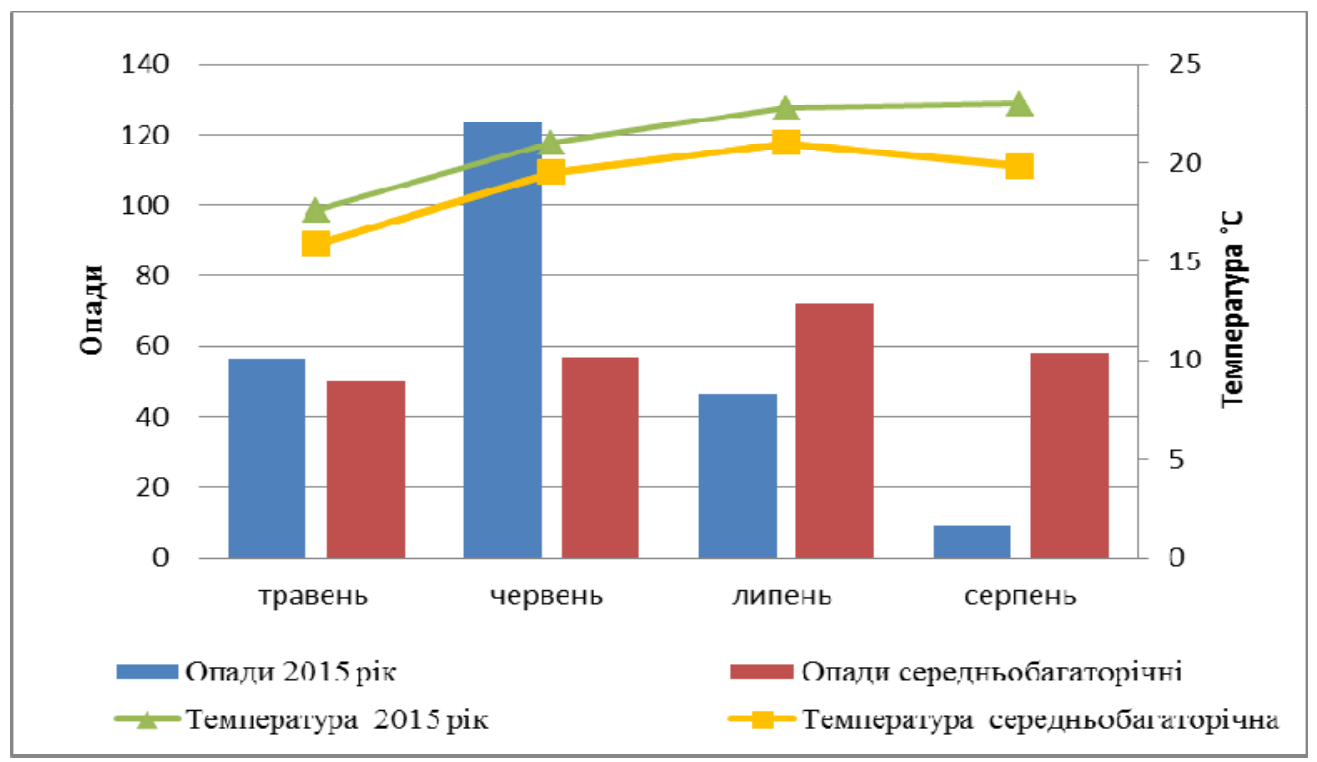

Рис. 1. Метеорологічні умови в період вегетації гречки, 2015 р.

\section{1. Продуктивність гречки в умовах 2015 року}

\begin{tabular}{|c|c|c|c|c|}
\hline \multirow{2}{*}{ Назва сорту } & \multicolumn{4}{|c|}{ Продуктивність, Г/ $\mathbf{m}^{2}$} \\
\cline { 2 - 5 } & \multicolumn{4}{|c|}{ Строки сівби } \\
\cline { 2 - 5 } & $\mathrm{I}(06.05 .15)$ & II (11.05.15) & III (16.05.15) & Середнє \\
\hline Ярославна & 386,0 & 341,9 & 262,9 & 330,3 \\
\hline Слобожанка & 277,9 & 274,4 & 227,5 & 259,9 \\
\hline СИН-3/02 & 318,3 & 333,7 & 332,1 & 328,0 \\
\hline Руслана & 268,1 & 193,1 & 217,9 & 226,4 \\
\hline Крупинка & 253,5 & 302,5 & 263,6 & 273,2 \\
\hline Українка & 233,3 & 305,2 & 300,6 & 279,7 \\
\hline
\end{tabular}

$\mathrm{HIP}_{0,05}$ (фактор А строки сівби) 29,21;

$\mathrm{HIP}_{0,05}$ (фактор Б сорти) 30,36;

$\mathrm{HIP}_{0,05}$ (фактор А і Б строки + сорти) 14,32 .

2. Елементи продуктивності сортів гречки, 2015 р.

\begin{tabular}{|c|c|c|c|c|c|c|c|c|}
\hline \multirow{2}{*}{ Назва сорту } & \multicolumn{4}{|c|}{ Маса 1000 зерен, г } & \multicolumn{4}{c|}{ Кількість зерен з рослини, шт. } \\
\cline { 2 - 3 } & \multicolumn{3}{|c|}{ Строки сівби } & \multirow{2}{*}{ Середнє } & \multicolumn{3}{|c|}{ Строки сівби } & \multirow{2}{*}{ Середнє } \\
\cline { 2 - 5 } & I & II & III & & I & II & III & \\
\hline Ярославна & 30,3 & 31,1 & 30,0 & 30,5 & 58,08 & 49,51 & 42,00 & 49,86 \\
\hline Слобожанка & 29,3 & 28,8 & 28,7 & 28,9 & 45,05 & 43,40 & 52,26 & 46,90 \\
\hline СИН-3/02 & 30,0 & 30,3 & 30,5 & 30,3 & 49,00 & 48,51 & 50,16 & 49,22 \\
\hline Руслана & 31,0 & 29,8 & 30,3 & 30,4 & 39,35 & 30,87 & 35,31 & 35,18 \\
\hline Крупинка & 31,7 & 30,6 & 30,8 & 31,0 & 36,27 & 45,42 & 39,94 & 40,54 \\
\hline Українка & 29,1 & 29,6 & 28,8 & 29,2 & 37,80 & 45,61 & 50,00 & 44,47 \\
\hline
\end{tabular}

$\mathrm{HIP}_{0,05}$ (фактор А строки сівби) 0,57;

$\mathrm{HIP}_{0,05}$ (фактор Б сорти) 0,58;

$\mathrm{HIP}_{0,05}$ (фактор А і Б строки + сорти) 0,92.

Середньомісячна відносна вологість повітря за період вегетації рослин була в межах 56-68 \% за середнього багаторічного показника 69 \%. Міні- мальна вологість спостерігалась від 19 до 38 \%.

Вивчення сортового матеріалу гречки (F. esculentum M.) в 2015 році за строками сівби 
дозволило встановити, що за звичайного рядкового способу сівби середньостиглий сорт Слобожанка дав максимальну продуктивність 277,9 г/м² за сівби 6 травня. Маса насіння з однієї рослини становила 1,3 г, а кількість його на рослині була в середньому по 45,1 штук.

Ранньостиглий сорт Руслана показав хороші результати першого і третього строку сівби (6 i

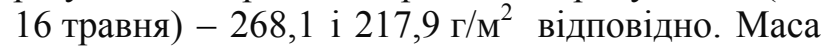
насіння 3 однієї рослини становила 1,2 і 1,1 г відповідно, а кількість його на одній рослині була в середньому по 39,4 і 35,3 штук відповідно.

Сорт Ярославна - ранньостиглий, він показав найвищу врожайність за першого строку сівби (06.05). Продуктивність його була максимальна

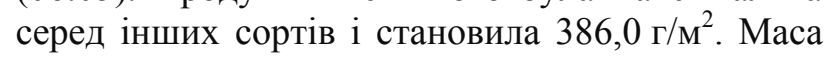
насіння 3 однієї рослини становила 1,8 г, а його кількість була в середньому по 58,1 штук. За другого строку сівби він мав також врожайні показники, які відзначалися від показників інших сортів, а за третього продуктивність й інші показників знижувалися.

У наших дослідженнях хороші результати показав середньо-ранній сорт СИН-3/02. Продук-

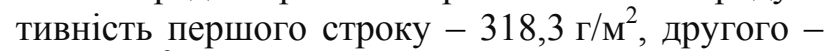
333,7 г/м ${ }^{2}$. Кількість насіння на одній рослині49,0 і 48,5 штук відповідно, а їх маса - 1,5 г.

Середньостиглі сорти Українка й Крупинка дали вищу продуктивність за сівби 11.05.2015 року (другий строк). Сорт Українка

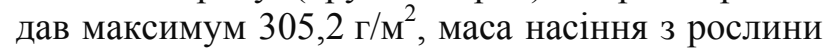
становила 1,4 г, а його кількість була в середньому по 45,6 штук.

Сорт середньостиглий Крупинка дав максимальну продуктивність 302,5 г/ $\mathrm{M}^{2}$. Маса насіння 3 рослини становила 1,4 г, а його кількість на рослині в середньому становила по 45,4 штук (табл. 1-2). Метеорологічні умови вегетаційного періоду 2016 року характеризувалися більш високою кількістю опадів в травні та серпні в порівнянні 3 середньобагаторічними показниками i попереднім роком, що в результаті вплинуло на формування високого рівня врожаю досліджуваних сортів.

Травень виявився дощовим - за 16 днів випало 89,5 мм за середнього багаторічного показника 50,0 мм. Середньомісячна температура повітря становила $16,9^{\circ} \mathrm{C}$ за багаторічного показника $15,9{ }^{\circ} \mathrm{C}$. Червень був теплим та сонячним, за місяць випало опадів 59,1 мм за багаторічного показника 57,0 мм. Середньомісячна температура повітря становила $21,5^{\circ} \mathrm{C}$ за середнього багаторічного значення $19,5^{\circ} \mathrm{C}$. Липень був спекотним, за 8 дощових дні випало 37,5 мм опадів за багаторічного значення 72,0 мм. Середня температура повітря в липні становила $24,1^{\circ} \mathrm{C}$ за багаторічного показника $21,0{ }^{\circ} \mathrm{C}$. У серпні спостерігалась суха і тепла погода. Середня температура повітря становила $22,8^{\circ} \mathrm{C}$ за середнього багаторічного показника $19,8^{\circ} \mathrm{C}$. За 9 дощових днів впродовж місяця випало 65,6 мм опадів, що на 7,6 мм більше за норму (58,0 мм) (рис. 2).

Середньомісячна відносна вологість повітря в період вегетації становила 66-73\%, мінімальна $-26-36 \%$.

Вивчення сортового матеріалу гречки (F. esculentum M.) в 2016 році за строками сівби дозволило встановити, що за звичайного рядкового способу сівби ранньостиглий сорт Руслана мав вищу продуктивність за першого строку сів-

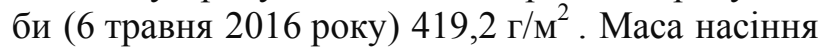
3 однієї рослини становила 1,9 г, а кількість його на одній рослині була в середньому по 61,5 штук.

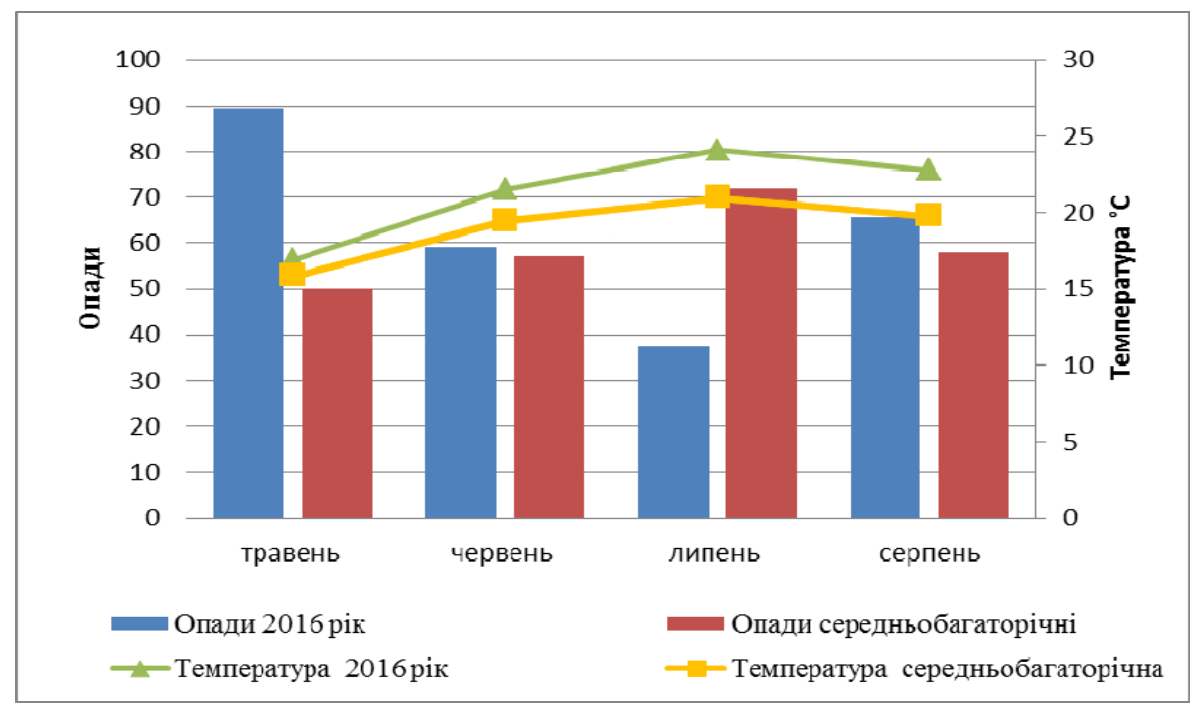

Рис. 2. Метеорологічні умови в період вегетації гречки, 2016 р. 
СТОРІНКА МОЛОДОГО ВЧЕНОГО

\section{3. Продуктивність гречки в умовах 2016 року}

\begin{tabular}{|c|c|c|c|c|}
\hline \multirow{3}{*}{ Назва сорту } & \multicolumn{4}{|c|}{ Продуктивність, г/м² } \\
\hline & \multicolumn{4}{|c|}{ Строки сівби } \\
\hline & I (06.05.16) & II (11.05.16) & III (16.05.16) & Середнє \\
\hline Ярославна & 379,2 & 319,2 & 350,3 & 349,6 \\
\hline Слобожанка & 313,0 & 264,2 & 243,7 & 273,6 \\
\hline СИН-3/02 & 422,8 & 376,3 & 384,3 & 394,5 \\
\hline Руслана & 419,2 & 343,1 & 354,4 & 372,2 \\
\hline Крупинка & 388,0 & 362,6 & 285,5 & 345,4 \\
\hline Українка & 343,4 & 307,0 & 333,0 & 327,8 \\
\hline
\end{tabular}

HIP $_{0,05}$ (фактор А строки сівби) 34,93;

$\mathrm{HIP}_{0,05}$ (фактор Б сорти) 46,43;

$\mathrm{HIP}_{0,05}$ (фактор А і Б строки + сорти) 76,46.

4. Елементи продуктивності сортів гречки, 2016 р.

\begin{tabular}{|c|c|c|c|c|c|c|c|c|}
\hline \multirow{2}{*}{ Назва сорту } & \multicolumn{4}{|c|}{ Маса 1000 зерен, г } & \multicolumn{4}{c|}{ Кількість зерен з рослини, шт. } \\
\cline { 2 - 3 } & \multicolumn{3}{|c|}{ Строки сівби } & \multirow{2}{*}{ Середнє } & \multicolumn{3}{|c|}{ Строки сівби } & \multirow{2}{*}{ Середнє } \\
\cline { 2 - 5 } \cline { 7 - 9 } & I & II & III & & I & II & III & \\
\hline Ярославна & 30,5 & 30,0 & 29,4 & 29,9 & 56,7 & 48,0 & 57,0 & 53,9 \\
\hline Слобожанка & 29,7 & 27,9 & 28,0 & 28,5 & 50,0 & 43,1 & 43,7 & 45,6 \\
\hline СИН-3/02 & 30,0 & 28,8 & 28,3 & 29,0 & 65,2 & 57,6 & 62,6 & 61,8 \\
\hline Руслана & 30,7 & 29,2 & 29,6 & 29,8 & 61,5 & 56,2 & 58,0 & 58,5 \\
\hline Крупинка & 30,6 & 30,6 & 28,8 & 30,0 & 57,8 & 54,8 & 46,2 & 52,9 \\
\hline Українка & 29,0 & 28,5 & 28,4 & 28,6 & 55,9 & 47,7 & 56,0 & 53,2 \\
\hline
\end{tabular}

НIP0,05 (фактор А строки сівби) 0,73;

НIP0,05 (фактор Б сорти) 1,11;

HIP0,05 (фактор А і Б строки + сорти) 1,90.

Середньостиглий сорт Слобожанка дав максимальну продуктивність насіння 313,0 г/ $\mathrm{M}^{2}$ за сівби 6 травня. Маса насіння з рослини становила 1,5 г, а кількість його на одній рослині була в середньому по 50,2 штук.

Сорт Ярославна - ранньостиглий, показав максимальну продуктивність за першого строку сівби (06.05) $379,2 \Gamma / \mathrm{m}^{2}$. Маса насіння 3 однієї рослини становила 1,7 г, а кількість його була в середньому по 56,7 штук.

Крупинка - середньостиглий сорт, дав найвищу продуктивність за сівби 06.05.2016 року (перший строк) 388,0 г $/ \mathrm{m}^{2}$, маса насіння 3 однієї рослини становила 1,5 г, а кількість його була в середньому по 57,8 штук.

Середньостиглий сорт Українка дав максимальну продуктивність за сівби 06.05.2016 року

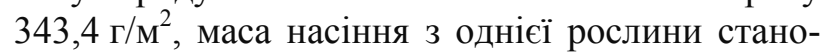
вила 1,6 г, а кількість його була в середньому по 55,9 штук.

У наших дослідах найпристосованішим до різних строків сівби в 2016 році виявився середньо-ранній сорт СИН-3/02. Він мав найбільшу кількість насіння з однієї рослини (в середньому по 61,8 штук) і найбільшу їх масу (1,8 г). Висока врожайність відзначалась за всіх строків сівби даного сорту (табл. 3-4).

Висновок. Для умов 2015 року встановлено, що такі елементи продуктивності гречки як крупність та кількість зерен із рослини мають суттевий вплив на формування продуктивності культури. За масою 1000 зерен виокремилися сорт Крупинка за раннього строку сівби, суттєві менші значення отримали за цим показником у сортів Слобожанка та Українка, відповідно, за сівби в перший та другий строк. Всі інші сорти за крупністю зерна мали середнє значення. Строки сівби сорту СИН-3/02 не мали впливу на елементи продуктивності.

В умовах 2016 року за крупністю зерна виокремилися сорти Ярославна, Руслана та Крупинка за раннього та середнього строків сівби. Усі сорти, що вивчалися, забезпечили вищу крупність зерна за раннього строку сівби за виключенням сортів Ярославна та Українка.

За результатами досліджень встановлено, що сорти гречки Українка, Крупинка, СИН-3/02 в умовах 2015 року найбільшу продуктивність 
формують за сівби в другій декаді травня. Сорти Руслана, Ярославна і Слобожанка краще висівати раніше. Максимальною їх продуктивність була за сівбі в першій декаді травня.

Вивчення сортового матеріалу гречки за стро-

\section{БІБЛІОГРАФІЯ}

1. Агробіологічні та екологічні основи виробництв гречки : Монографія / В. Я. Білоножко, А. П. Березовський, С. П. Полторецький, Н. М. Полторецька ; За ред. В. Я. Білоножка. - Миколаїв: Видавництво Ірини Гудим, 2010. - 332 с.

2. Державний реєстр сортів рослин, придатних до поширення в Україні у 2018 році [Електронний pecypc]. - Режим доступу: http://sops.gov.ua/uploads/page/5ad9a8180cflf.pdf.

3. Дороничева В. И. Высокие урожаи гречихи (опыт колхоза имени Жданова Тульской области) / В. И. Дороничева, Н. В. Захаров. - М. : Россельхозиздат, 1981. - 62 с.

4. Доспехов Б. А. Методика полевого опыта с основами статистической обработки результатов

\section{ANNOTATION}

Ul'ianchenko M. S. The influence of the timing of planting on the productivity of buckwheat.

The set of optimal sowing dates of the buckwheat is to the actual value on the background of unstable weather of the springtime.

In the article, six species of buckwheat (Fagopyrum esculentum Moench) of domestic breeding: Yaroslavna, Slobozhanka, Ruslana, Ukrainka, Krupynka, SIN-3/02 were studied experimentally, depending on the time of sowing in conditions of unstable moisture of the Central Forest-Steppe. For research, conventional methods and special methods were used: productivity of buckwheat varieties and analysis of grain material by the elements of productivity were determined after purification of the grain by air separation method and converted to a standard $14 \%$ moisture content.

For the 2015 conditions it has been established that the elements of the buckwheat productivity: the size and number of grains from the plant have a significant effect on the formation of the productivity of the crop. By weight of 1000 grains, Krupynka variety was distinguished at early term ками сівби в 2016 році дозволило встановити, що всі сорти, висіяні першого строку, в умовах нестійкого зволоження центрального Лісостепу давали вищу продуктивність в порівнянні 3 іншими строками.

исследований / Б. А. Доспехов. - М. : Колос, 1985. - 315 c.

5. Елагин И. Н. Агротехника гречихи / И. Н. Елагин. - М.: Колос, 1984. - 127 с.

6. Зотиков В. И. Ресурсосберегающая технология производства гречихи: метод. рек. / В. И. Зотиков, 3. И. Глазова и др. - Орел : ГНУ ВНИИЗБК, 2009. - 40 с.

7. Царенко О. М. Комп'ютерні методи в сільському господарстві та біології : Навчальний посібник / О. М. Царенко, Ю. А. Злобін, В. Г. Скляр. Суми : Університетська книга, 2000. - 203 с.

8. Якименко А. Ф. Гречиха / А. Ф. Якименко. М. : Колос, 1982. - 196 с.

sowings; significant lower values were obtained for this variety in Slobozhanka and Ukrainka, respectively for sowing in the first and second terms. All other varieties according to grain size had an average value. The lines of sowing of the variety SIN-3/02 did not influence the elements of productivity.

In the conditions of 2016, the varieties Yaroslavna, Ruslana and Krupynka were distinguished by grain size for early and medium term sowing. All varieties put on the study ensured a higher grain size in early sowing, with the exception of Yaroslavna and Ukrainka varieties.

According to the results of two-year studies, it has been determined that early varieties of buckwheat Yaroslavna and Ruslana should be sown from the middle of the first decade of May. Sloboda and Krupynka grades produce the highest seed yields in the first and second lines. The exact effect of the sowing date on this indicator in the varieties SIN-3/02 and Ukrainka was not detected.

Key words: varieties, meteorological conditions, number of grains, amount of precipitation, air temperature. 